\title{
Effect of various levels of spacing and salicylic acid treatment on vegetative growth and flowering of gladiolus (gladiolus grandiflora 1. ) cv. White prosperity
}

\author{
Virendra Pal ${ }^{1}$, Mani Ram²and Mukesh Kumar ${ }^{3}$ \\ ${ }^{1}$ Krishi Vigyan Kendra, Hastinapur, SVP Univ. of Agric. \& Tech. Meerut-250110 (U.P.) \\ ${ }^{2 \& 3}$ Department of Horticulture, SVP Univ. of Agric. \& Tech. Meerut-250110 (U.P.)
}

\begin{abstract}
An experiments were carried out to study of the effect of various level of spacing and salicylic acid treatment on vegetative growth and flowering of gladiolus cv. white prosperity, in factorial Randomized Block Design (RBD) at Department of Horticulture, Horticulture Research Center (HRC), Sardar Vallabhbhai Patel University of Agriculture \& Technology, Meerut (UP) during 2008-09. The treatments consist of three various spacing i.e., $20 \times 10$, $20 \times 20$ and $20 \times 30 \mathrm{~cm}$ and salicylic acid between 0,50 and $100 \mathrm{ppm}$ were applied uniformly for all the treatments during the crop period Out of these a optimum spacing $20 \times 20 \mathrm{~cm}$ was found superior with $100 \mathrm{ppm}$ salicylic acid concentration in respect of number of leaves leaf $(\mathrm{cm})$. length of opening of $1^{\text {st }}$ floret visibility of first spike, spike length, and number of florets per spike.
\end{abstract}

Keywords: Gladiolus, Corm, Spacing and Salicylic Acid.

Gladiolus is a popular cut flower owing to its variation in colour, spike, sturdiness, appearance and multiple use in flower arrangements and bouquets. It belongs to family iridaceae and originated from south Africa. The word gladious is derived from Latin word gladious means a sword lily because of sword like leaves. It is a most important flowering plants and having fourth rank in international market in cut flower trade. It is gaining fast popularity in India. Demand of its flower for bouquet is increasing day to day to its economic value. The cut flower is popular for its attractive spikes having florets for hedge form, dazzling colour, wearying sizes and long keeping quality. Due to its longer base life, it is use in different floral arrangement.

For obtaining good quality production of gladiolus flowers, spacing play an important role for obtaining good plant growth, quality spikes, corm and cormel production (Singh, 2000; Bijimol and Singh, 2001). Therefore, presents study was conducted with a view to find out the optimum planting spacing and chemical for obtaining good vegetative growth superior quality of spikes and increasing of flower in gladiolus cv. white prosperity.

\section{Materials and methods}

A study on the effect of various spacing and salicylic acid treatment on vegetative growth and flowering of Gladiolus (Gladiolus grandiflora L.) cv. white prosperity was conducted at Department of Horticulture, Horticulture Research Centre (HRC), Sardar Vallabhbhai Patel University of Agriculture \& Technology, Meerut (UP), during 2008-09. The experiment was laid out in a factorial randomized block design with six treatments and three replications. Fully developed medium size corms were sown for planting purpose than treated with carbandazim @2.0gm per liter water of dried in shade.The treated corm were planted in well prepared field at various 
spacing between $20 \times 10,20 \times 20$ and $20 \times 30 \mathrm{~cm}$ and salicyclic acid between 0,50 and $100 \mathrm{ppm}$ were applied uniformly for all the treatments during the cropping period. A recommended dose of nitrogen, phosphorus and potash was applied in field. The half dose of nitrogen and full dose of phosphorus and potash were applied as basal dose at the time of final preparation of field before planting of corms. Whereas remaining half dose of nitrogen was applied at the time of first flower spike emergence. During the experimentation, data were recorded in terms of growth and flowering parameters with using standard methods. Statistical analyses were carried out as suggested by Gomez and Gomez (1996).

\section{Results and discussion}

Vegetative Growth Characters: Data presents in Table 1 revealed that significantly influenced vegetative characters of gladiolus. Similarly, vegetative growth $\left(\mathrm{H}_{2}\right)$ took least number of sprouts per plants (9.80) while larger growth $\left(\mathrm{H}_{1}\right)$ delayed (10.33) sprouting, however, it was at per plant with $\mathrm{S}_{2}$ (10.26) and $\mathrm{H}_{0}$ (10.11) treatments. It have been observed early and late sprouting of gladiolus. Plants height, number of leave per plants, length of leave and width of leaf increased from smallest to largest recorded. Significantly maximum height of plants $S_{2}(105.32 \mathrm{~cm})$ and number of leave per plants $S_{3}(12.63)$ was recorded at 100 days after planting of corm under the treatment, where the plant were spaced at $20 \times 30$ $\mathrm{cm}$. during the course of investigation. The average maximum length of the longest leaf ( 68.83 $\mathrm{cm}$.) and width of leaf $(3.03 \mathrm{~cm})$ was recorded after 100 days planting of corm under the treatment $\mathrm{H}_{2}$, where salicylic acid spray was applied@100 ppm. However, the average minimum width of the leaf $(2.74 \mathrm{~cm}$.) was recorded under $S_{1}$ treatment, under the closer i.e. $20 \times 10 \mathrm{~cm}$ after the second wider spacing $20 \times 30 \mathrm{~cm}$ it was might be due to the space providing between the plants. (Sujata and Singh, 1991) The optimum plant spacing is provide the optimal amount of nutrients, space, sun light etc. regarding the number of sprouts and plant height. Similarly maximum number of leaves per plant, light of leaf and width of leaf are due to the effect of sufficient space and maximum exposure to sun light which enhance the photosynthesis. These findings are closely related with the finding of ( Sujatha and Singh, 1991; Yadav and Singh 1996 and Singh, 2000).

Similarly, the various doses of salicylic acid in the form of foliar application were gave the significant effect on different growth parameter as compared to control and other treatments during the experimentation. Data presented in Table 1 shows that the non-significatn results was recorded in terms of number of sprouts per plant. The maximum plant height $\mathrm{H}_{1}(104.83 \mathrm{~cm})$ was recorded with an application of $50 \mathrm{ppm}$ salicylic acid and minimum plant height $\mathrm{H}_{0}(99.45 \mathrm{~cm})$ was obtained under the control treatment after the higher level of salicylic acid i.e., 100ppm. The other parameters like number of leaves per plant, leaves per plant, leaf length and width was also significant increased upto zero to $100 \mathrm{ppm}$ acid. The maximum number leaves per plant $\mathrm{H}_{2}$ (11.83), length of leaf $\mathrm{H}_{2}$ (68.83) and width of leaf $\mathrm{H}_{2}$ $(3.03 \mathrm{~cm})$ were observed with higher level of salicylic acid (100ppm), while minimum number of leaves $\mathrm{H}_{0}$ (8.73) length of leaf $\mathrm{H}_{0}(64.86 \mathrm{~cm})$ and width of leaf $\mathrm{H}_{0}(2.78 \mathrm{~cm})$ were recorded in control treatment. The salicylic acid is gave the favorable effect on growth parameters, because it is a growth promoting chemical. It accelerates the cell divisions in the apical portion of the sprouts in gladiolus. The above findings are close in conformity with the findings of (Sakhabutdinova, et al. 2003).

Floral Characters: The data pertaining from the Table 2 revealed that the various levels of spacing and of salicylic acid treatment significantly affect the flowering of gladiolus over the control. The minimum days taken in terms of visibility of spike and days to opening $1^{\text {st }}$ florest i.e. 93.24 and 105.17 days were recorded under the wider spacing $20 \times 30 \mathrm{~cm}$, whereas maximum visibility days of first spike (104.04) and days to opening $1^{\text {st }}$ floret (115.97) days were taken with spacing i.e. $20 \times 10 \mathrm{~cm}$ followed by optimum spacing $20 \times 20 \mathrm{~cm}$ with values i.e. 97.88 and 110.64 days in terms of 
visibility of first spike and days to opening of $1^{\text {st }}$ florets. Similar results were also obtained with different doses of salicylic acid. In this regards, the minimum visibility of $1^{\text {st }}$ spike (90.77 days) and days to opening $1^{\text {st }}$ floret (102.27days) were noticed under the higher dose of salicylic acid i.e., $100 \mathrm{ppm}$. However, the maximum days taken to visibility of first spike and days to opening $1^{\text {st }}$ flirt viz., 108.09 and 119.38 days respectively.

In context of spike length, the maximum length of spike $96.53 \mathrm{~cm}$ was observed with wider spacing $20 \times 30 \mathrm{~cm}$, whereas minimum length of spike noted under closer spacing i.e. $20 \times 10 \mathrm{~cm}$ followed by optimum spacing $20 \times 20 \mathrm{~cm}$. However the salicylic acid concentration were also significantly affected the spike length upto $50 \mathrm{ppm}$. Salicylic acid then it was noted as detrimental factor. The maximum length of spike $101.54 \mathrm{~cm}$ was recorded under $50 \mathrm{ppm}$ salicylic acid whereas, minimum $(86.14 \mathrm{~cm})$ was obtained under control followed by higher concentration of salicylic acid. The another flowering character like rachis length were also noted in favorable trend. The longest $(95.07 \mathrm{~cm})$ rachis length was recorded with closer spacing $20 \times 10 \mathrm{~cm}$ and minimum $(66.45 \mathrm{~cm})$ was reported under $20 \times 30 \mathrm{~cm}$ spacing followed by $20 \times 20 \mathrm{~cm}$. The rachis length significantly affected by salicylic doses with increasing upto zero to 50 ppm then it was declined with higher concentration i.e., $100 \mathrm{ppm}$ salicylic acid. The maximum $(69.70 \mathrm{~cm})$ rachis length was recorded with a dose of 50 ppm salicylic acid, while minimum $(59.70 \mathrm{~cm})$ rachis length was observed with $100 \mathrm{ppm}$ salicylic acid followed by control $(64.75 \mathrm{~cm})$.

The floral diameter was found significant with all the leaves of spacing and salicylic acid. The various spacing and salicylic acid concentration were significantly affecting the number of florets per spike with increasing levels of both the treatments over control. The maximum (14.45) number of florets were found under wider spacing $20 \times 30 \mathrm{~cm}$ whereas, minimum (11.08) number of florets were recorded under the closer spacing followed by $20 \times 10 \mathrm{~cm}$ spacing. Similar result were also reported with various concentration of salicylic acid. The maximum (14.97) number of floret per spike were observed with $100 \mathrm{ppm}$ salicylic acid and minimum number of florets (11.95) were under control followed by $50 \mathrm{ppm}$ salicylic acid. The positive response of wider spacing provide space between the plants resulting plants absorbed optimum amount of nutrient with sufficient light, which ultimately favorable for photosynthesis and translocation of assimilates into the storage organs. These changes in plant system are also responsible for improving flowering parameters i.e. visibility, days to open $1^{\text {st }}$ florets spike length, rachis length, floral diameter and number of florets. These findings are in close conformity with the earlier findings reporte by Khurana and Cleland (1992).

Table 1: Effect of spacing and salicylic acid on vegetative growth character of Gladiolus

\begin{tabular}{|c|c|c|c|c|c|}
\hline Treatments & $\begin{array}{l}\text { No. of Sprouts } \\
\text { /plants }\end{array}$ & $\begin{array}{l}\text { Plant Height } \\
\text { (cm) }\end{array}$ & $\begin{array}{c}\text { No. of Leave / } \\
\text { plants }\end{array}$ & $\begin{array}{l}\text { leaf length } \\
\text { (cm) }\end{array}$ & $\begin{array}{l}\text { leaf width } \\
\text { (cm) }\end{array}$ \\
\hline \multicolumn{6}{|c|}{ Spacing } \\
\hline $\mathrm{S}_{1}(20 \times 10 \mathrm{~cm})$ & 9.87 & 101.62 & 9.56 & 64.44 & 2.74 \\
\hline $\mathrm{S}_{2}(20 \times 20 \mathrm{~cm})$ & 10.26 & 105.32 & 10.64 & 66.94 & 2.90 \\
\hline $\mathrm{S}_{3}(20 \times 30 \mathrm{~cm})$ & 10.08 & 103.59 & 12.63 & 67.28 & 3.01 \\
\hline \multicolumn{6}{|c|}{ Salicylic acid } \\
\hline $\mathrm{H}_{0} \quad 0 \mathrm{ppm}$ & 10.11 & 99.45 & 8.73 & 64.86 & 2.78 \\
\hline $\mathrm{H}_{1} 50 \mathrm{ppm}$ & 10.33 & 104.83 & 9.06 & 65.03 & 2.93 \\
\hline $\mathrm{H}_{2} 100 \mathrm{ppm}$ & 9.80 & 101.24 & 11.83 & 68.83 & 3.03 \\
\hline $\mathrm{CD}$ at $5 \%$ & NS & 1.81 & 0.30 & 1.11 & 0.05 \\
\hline
\end{tabular}


Table 2: Effect spacing and salicylic acid on flowering characters of Gladiolus.

\begin{tabular}{|l|c|c|c|c|c|c|}
\hline Treatments & $\begin{array}{c}\text { Visibility of } \\
\text { first spike } \\
\text { (days) }\end{array}$ & $\begin{array}{c}\text { Days to } \\
\text { opening of } \\
\text { Ist floret }\end{array}$ & $\begin{array}{c}\text { Spike } \\
\text { length } \\
\text { (cm) }\end{array}$ & $\begin{array}{c}\text { Rachis } \\
\text { length }(\mathbf{c m})\end{array}$ & $\begin{array}{c}\text { Floral } \\
\text { diameter } \\
\text { (cm) }\end{array}$ & $\begin{array}{c}\text { No. of } \\
\text { florets } / \\
\text { spike (cm) }\end{array}$ \\
\hline \multicolumn{7}{|c|}{ Spacing } \\
\hline $\mathrm{S}_{1}(20 \times 10 \mathrm{~cm})$ & 104.04 & 115.97 & 90.61 & 95.07 & 10.68 & 11.08 \\
\hline $\mathrm{S}_{2}(20 \times 20 \mathrm{~cm})$ & 97.88 & 110.64 & 94.37 & 67.95 & 10.70 & 12.86 \\
\hline $\mathrm{S}_{3}(20 \times 30 \mathrm{~cm})$ & 93.24 & 105.17 & 96.53 & 66.45 & 40.90 & 14.45 \\
\hline \multicolumn{7}{|c|}{ Salicylic acid } \\
\hline $\mathrm{H}_{0} 0 \mathrm{ppm}$ & 108.09 & 119.38 & 86.14 & 64.75 & 10.80 & 11.95 \\
\hline $\mathrm{H}_{1} 50 \mathrm{ppm}$ & 96.51 & 108.13 & 101.54 & 69.70 & 11.00 & 12.97 \\
\hline $\mathrm{H}_{2} 100 \mathrm{ppm}$ & 90.77 & 102.27 & 93.83 & 59.70 & 11.10 & 14.97 \\
\hline $\mathrm{CD}_{\mathrm{n}}$ at $5 \%$ & 2.16 & 1.75 & 2.11 & 0.70 & $\mathrm{NS}$ & 1.33 \\
\hline
\end{tabular}

\section{Conclusion}

On the basis of results obtained, it can be concluded that spacing of $20 \times 20 \mathrm{~cm}$ and $100 \mathrm{ppm}$ of salicylic acid concentration should form the integral part of gladiolus cultivation and packing of practices for getting a good and profitable crop of gladiolus under agro-climatic conditions of Meerut region of Western Uttar Pradesh.

\section{References}

1. Bijimol, G. and A.K. Singh (2001). Effect of spacing and nitrogen on gladiolus under Nagaland condition. J. Orna. Hort. 4(1): 36-39.

2. Gomes, V. and Gomez, O.R. (1996) Statistical method for research worker. Olier and Boyd, Elibburgl. P-250.

3. Khurana, J.P. and Cleland, C.F. (1962). Role of Salicylic acid and bezoic acid in flowering of a photoperiodinsensitive strain, Lemna paucicostala LP 61. Plant Physics 100: 1541 1546.

4. Sakhabntdinova, A.R., Fatkhat Kinova, D.R., Bezrukova, M.V. and Shakiroga F.M. (2003). Salicylic acid prevents the damaging action of stress factors on wheat plants Bulg. J. Plant Physical Period ISSU. 314-319.

5. Singh, K. P. (2000). Growth, flowering and corm production in gladiolus as effected by different corm sizes. J. Orna. Hort. New Series. 3(1):26-29

6. Sujatha, K. and Singh, K.P. (1991). Effect of different planting densities on growth, flowering and corn production in Gladiolus. Indian J. Horti. 48(3): 273-276.

7. Yadav, S.K. and Singh, K.P (1996). Effect of corm size and spacing on growth and flowering of gladiolus or. Sylvia. Plant Archives. 7(1): 346-344 